\title{
Bank Insolvency Procedures as a Foundation for Market Discipline
}

\author{
Angkinand, Apanard; Wihlborg, Clas
}

Document Version

Final published version

Publication date:

2005

License

CC BY-NC-ND

Citation for published version (APA):

Angkinand, A., \& Wihlborg, C. (2005). Bank Insolvency Procedures as a Foundation for Market Discipline. LEFIC Working Paper No. 2005-08

Link to publication in CBS Research Portal

\section{General rights}

Copyright and moral rights for the publications made accessible in the public portal are retained by the authors and/or other copyright owners and it is a condition of accessing publications that users recognise and abide by the legal requirements associated with these rights.

Take down policy

If you believe that this document breaches copyright please contact us (research.lib@cbs.dk) providing details, and we will remove access to the work immediately and investigate your claim.

Download date: 26. Apr. 2023 


\section{LEFIC}

Copenhagen Business School

\section{Center for Law, Economics and Financial Institutions at CBS}

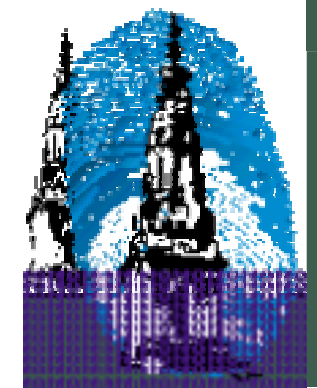

LEFIC WORKING PAPER 2005-08

Bank Insolvency Procedures as a Foundation for Market Discipline

Apanard Angkinand and

Clas Wihlborg

www.cbs.dk/LEFIC 


\title{
Bank Insolvency Procedures as a Foundation for Market Discipline
}

\author{
Apanard Angkinand \\ University of Illinois at Springfield
}

\author{
Clas Wihlborg \\ Copenhagen Business School and University of California at Riverside
}

Oct. 31, 2005

\begin{abstract}
:
Predetermined, operational procedures for dealing with banks in distress are conspicuously absent across the world with very few exceptions. Instead governments and regulatory authorities intervene when banks approach failure. Bail-outs of important creditors, sometimes including shareholders, and blanket guarantees for creditors become the norm. We argue that efficient incentives of banks' creditors, as well as of shareholders and managers, require predetermined rules for dealing with banks in distress, and a group of creditors that are credibly non-insured. Cross-border banking increases the need for pre-determined bank insolvency procedures that could enable banks to expand cross-border in branches. In the empirical part we show that credibility of non-insurance is maximized with a partial deposit insurance scheme, and that the coverage can be decreased if effective rule-based distress resolution procedures are implemented.
\end{abstract}




\title{
Bank Insolvency Procedures as a Foundation for Market Discipline
}

\author{
Apanard Angkinand \\ University of Illinois at Springfield \\ Clas Wihlborg \\ Copenhagen Business School and University of California at Riverside
}

\section{Introduction}

Formal and informal insolvency procedures for dealing with distressed firms constitute an essential part of a competitive market mechanism by allowing exit of inefficient firms and the reallocation of resources to new ventures, or by contributing to rehabilitation and reorganization of firms. Efficient procedures provide contractual predictability for stakeholders in the sense that they can value their claims contingent on a firm's economic condition. The contractual predictability contributes to the ex ante incentives of investors, lenders and other stakeholders to commit resources.

Predetermined, operational procedures for dealing with banks in distress are conspicuously absent across the world with very few exceptions. Instead governments and regulatory authorities intervene when banks approach failure for reasons that will be discussed. Bail-outs of important creditors, sometimes including shareholders, and blanket guarantees for creditors become the norm rather than the exception. Incentives of stakeholders in banks become distorted and the competitive mechanism dysfunctional.

In this paper we argue that efficient incentives of banks' creditors, as well as of shareholders and managers, require predetermined rules for dealing with banks in distress, and a group of creditors that are credibly non-insured. Predetermined bank insolvency procedures--if appropriately designed--contribute to the credibility of non-insurance of creditor groups. This credibility requires that distress resolution for banks can be implemented without the issuance of ad hoc guarantees at the time of distress.

Cross-border banking increases the need for pre-determined bank insolvency procedures. Herring (2002) coined the phrase "Too Complex to Fail" to describe the international financial conglomerates supplying financial services in a number of countries in an often opaque subsidiary structure. Following Goldberg, Sweeney and Wihlborg (2005) we argue here that appropriate, credible bank insolvency procedures make it possible to integrate banks' crossborder activities across home-and host countries in branches supervised by home country authorities Thus, the seemingly distant EU vision of competition between international banks with mutual recognition of supervisors and regulation could be realized.

In the empirical part of this paper we provide evidence based on Angkinand and Wihlborg (2005a) that market discipline on banks is enhanced by credibility of non-insurance. We show how our proxies for lack of market discipline--the probability of banking crisis and nonperforming loans in a sample of developed and emerging market countries--depend on the coverage of explicit deposit insurance schemes in these countries. The analysis of Angkinand and Wihlborg (2005a) is then extended to capture effects of rule-based insolvency procedures in the USA in particular. 


\section{Insolvency Procedures for Banks ${ }^{1}$}

Efficient insolvency procedures allow appropriate restructuring, debt-reduction, management change, liquidity infusion or other actions to take place. The difficulty of designing efficient insolvency procedures is to a large extent caused by information problems and asymmetries of information about the cause of distress and asset values. Collateralized loans and priority rules discourage "runs" on the available resources of a distressed firm. A run can force a firm into bankruptcy prematurely. In banking this "run problem" is particularly acute. Guarantees of creditor groups, such as deposit insurance for banks' creditors, can discourage runs but they make creditors insensitive to risk and, thereby, they cause misallocation of resources.

In countries with explicit restructuring law such as Ch. 11 in the US, an independent body with enforcement powers, such as a court, is required to determine the value of the firm and the value-maximizing course of action. Contracts are abrogated when firms enter restructuring proceedings. Therefore, the predictability of the outcome for various stakeholders is low and the outcome is generally more favorable to the shareholders and management than the outcomes in countries with a more liquidation oriented approach to insolvency. Predictability and, therefore, ex ante efficiency is also influenced by arbitrariness of court procedures, corruption of judges, and political influences on procedures.

Although the role of insolvency procedures for banks in principle is the same as for nonfinancial firms and non-bank financial firms, there are important differences between banks and other firms. First, banks supply liquidity. A large part of their liabilities are very short term and they play an important role in the payment mechanism. These liabilities may be subject to bank runs if creditors fear non-repayment. Second, there are generally substantial amounts of very short term interbank liabilities that may contribute to contagion among banks if one bank fails. Third, creditors of banks in particular are diverse and many. Thus, banks do not generally have one or a few large creditors with a strong interest in resolution of distress. The risk of runs on a bank in distress and contagion implies that speed of action in distress resolution is of the essence. Conventional liquidation and restructuring procedures are too time-consuming to be applied to banks without modification.

For the reasons mentioned regular bankruptcy-and restructuring laws are not often applied in cases when banks face distress. One could argue that in countries with extensive deposit insurance, the insuring authority could take the coordinating role that large creditors often have in non-bank re-structurings. However, in many countries the insuring authority may be the government and, even if there is a specific authority, there are in most countries neither pre-established procedures for settling claims against non-insured creditors, nor the expertise in the authority to manage the insolvency. Most countries simply do not allow banks to fail. The main exception is the USA that has implemented bank-specific insolvency procedures through the FDIC. We return to practices in different countries in the next section.

Although many economists have argued that the fear of contagion from one bank's failure is exaggerated, few governments are willing to test this belief. A regulatory authority facing an actual or perceived threat to the banking system is compelled to respond in order to eliminate the risk of bank runs. The authority or its government may bail out banks fully or partially--even nationalize the banking sector, as in Norway in the late 1980s. Other solutions include (a) debt restructuring, (b) a mix of government and more or less voluntary private recapitalization, and (c) the creation of specialized agencies to take over bad loans, such as the Resolution Trust Corporation in the USA. 
The mentioned solutions may assist in restoring a functioning market, but they tend to be assembled by regulators, central banks and governments in time of crises. Therefore, they fail to provide the sector with transparent, predictable consequences in cases of mismanagement or excessive risk-taking. When the crisis occurs the political pressures to resolve it by protecting strong interest groups are high. Ex ante knowledge of these political pressures lead to expectations of bail-outs and comprehensive liability guarantees.

Transparent, pre- and well-specified insolvency procedures for banks could increase the credibility of no bail-out policies, enhance market discipline and thereby reduce the probability of banks facing distress, and where distress occurs, prevent one bank's failure from having contagion effects.

Given the specific characteristics of banks, liquidation-and restructuring procedures for non-banks are not practical in the banking sector. One alternative, Prompt Corrective Action (PCA), has been implemented in the US. It offers a degree of predictability of actions for shareholders and management although substantial discretion remains. Insolvency rules should allow both liquidation and restructuring. They would complement PCA by being more complete and predictable with respect to the claims of different stakeholders.

The European Shadow Financial Regulatory Committee (1998) proposed the following characteristics of special bank insolvency procedures:

1. Pre-specified trigger capital levels for pre-specified regulatory or legal action (PCA)

2. A pre-determined trigger initiating liquidation. This trigger point may actually be set at a positive capital ratio given uncertainty about asset values.(part of PCA)

3. Priority among creditors must be contractually pre-specified in such a way that claims with high liquidity value are given high priority.

4. Valuation procedures should be made transparent.

5. In liquidation other banks or the central bank need to be organized to honor claims with high liquidity value including interbank claims on behalf of the distressed bank. Banks may have incentives to organize such arrangements themselves, if clear liquidation procedures exist, but if they do not, then regulators must make sure that arrangements exist.

6. The lender of last resort function should not be extended to insolvent banks.

7. The authorities managing a crisis must be made independent of ad hoc political pressures in order to enhance the credibility of the process.

The implementation of insolvency law for banks with these characteristics should achieve an acceptable, low risk of runs and low risk of contagion while inefficient owners and managers exit. The contractual predictability of claims and the predictability of bankruptcy and PCA-costs should provide efficient ex ante incentives. By achieving these objectives the government's and the regulator's fear of a system crash should be alleviated. Thereby, non-insurance of groups of creditors and shareholders would be credible.

\section{Current distress resolution practices in banking ${ }^{2}$}

The USA with its high coverage deposit insurance system has been leading in the creation and implementation of pre-specified rules. The Federal Deposit Insurance Corporation Improvement Act (FDICIA) of 1991 sets trigger capital ratios for specific "prompt corrective actions" by banks and regulatory authorities. There are four trigger points at which the FDIC in particular must take action or order the bank to take certain actions. The Fed's ability to act as "Lender of 
Last Resort" has been strongly restricted unless there is substantial systemic risk. Questions remain, however, about the ability and willingness of the Fed and the FDIC to follow the PCAprocedures if a bank in distress is considered "too big to fail". Nevertheless, PCA increases the predictability of distress costs for shareholders at different levels of capital providing incentives for shareholders and management to have a sufficient capital buffer corresponding to risk taking. ${ }^{3}$

Norway is another country with pre-specified distress resolution procedures for banks. Already before the Norwegian banking crisis in the late 80s, there were rules for "public administration" of banks in distress. The procedures are more similar to liquidation procedures than to restructuring procedures and the distressed bank is not expected to remain under public administration for long. The Norwegian case illustrates that it is not merely the existence of predetermined insolvency procedures that matter. Banking in Norway is dominated by a few banks. Each one tends to be "too big to fail". Therefore, liquidation is not a politically acceptable alternative and liquidation procedures will not be enforced. Thereby, they lose credibility.

The vast majority of countries lack formal distress resolution procedures for banks. Regular bankruptcy laws apply in principle on banks. In some countries insolvency law may include procedures that are particularly suitable for banks. In particular, the UK insolvency law includes a procedure called "administration" designed to enable reconstruction of a firm. An "administrator" can be appointed by a group of creditors or a court to lead a distressed firm The administration procedures are similar to Chapter 11 in several ways except that the administrator takes over management functions. In administration, firms are protected from actions by creditors while negotiations with creditors are ongoing. The intention of administration is to be short lived and the administrator can enter new agreements with the purpose of avoiding liquidation. Existing contracts remain valid, however.

After 1997 the British FSA has been given strong authority to issue rules for banks with the purpose of ensuring financial stability. The FSA can force a bank to enter bankruptcy or administration proceedings. It has the right to issue opinions about the result of administration proceedings. The division of responsibility between the FSA, the Bank of England, and the Ministry of Finance has been specified in a "Memorandum of Understanding".

As a country experiencing a severe banking crisis in the early 90s, Sweden has had a debate about distress resolution procedures during the 90s. The Swedish banking crisis was essentially resolved by the issuance of a blanket guarantee for all bank creditors. Even shareholders were indirectly bailed out by this guarantee. In 2000 a government committee proposed specific legislation for a separate insolvency law for banks, much in the spirit of the European Shadow Committee proposal described above. Specifically, the proposal for "public administration" contained a mixture of the American and the Norwegian rules. Like the American FDICIA the purpose of the proposed procedures was primarily to make restructuring possible. Liquidation procedures were also clearly specified. For example, the liquidity problem was addressed directly. The proposal is "resting" after being positively received although some reservations on specifics were expressed by, for example, the Swedish FSA.

Crisis management for banks is an issue addressed in Europe as well on the EU level. In particular, the coordination problem arising when an international bank faces distress has led to some activity with respect to development of principles for crisis resolution. Since most major banks within the EU have some international activity, these principles are the closest the EU comes to insolvency procedures for banks. 
In a "Report on Financial Crisis Management" the Economic and Financial Committee ${ }^{4}$ states that "there is no blueprint for crisis management" and as a general principle "private institutions should be involved as much as possible in both crisis prevention and, if this fails, in crisis management......If financial losses occur, the firm's shareholders should bear the costs and its management should suffer the consequences. For this reason, the winding down of the institution may be a sensible strategy." EU crisis management procedures do not become more specific than this.

Other sections of the report refer to alternative solutions in a bank crisis. Private sector solutions are "preferred" but "Liquidity support might have to be granted in order to stabilise the troubled institution or the market as a whole in order 'to buy time'. In a less volatile environment, public measures may then be considered, if the winding-down of the institution is not a viable option." Competitive implications of crisis management measures are also discussed in a separate section.

The implication for crisis management of these very general principles is that central banks, financial supervisors, and responsible ministries will become involved when a bank faces distress. The lack of clear procedures in combination with the need to act quickly and the political incentives to protect depositor groups creates a system where the authorities are obliged to support the distressed bank.

\section{Market discipline in cross-border banking; “Too Complex to Fail” vs "Too Big to Save”?}

Cross-border banking can occur through subsidiaries or branches in the host countries. In this section we discuss distress resolution procedures for the subsidiary organization before turning to the branch organization. Subsidiaries are by far the most common form of host country establishment in retail banking. Branches are, with few exceptions not accepted by host country regulators.

Subsidiaries are independent legal entities subject to host country law, regulation and supervision. Their assets are more or less controlled by the parent, however. Cross-border banks can therefore engage in opportunistic risk-shifting, possibly with the consent of the home country supervisor, who may approve of more risk being placed in host countries with weaker supervision.

As noted by Herring (2004) financial conglomerates operating with subsidiaries in several countries tend to become "Too Complex to Fail". Crisis resolution must involve authorities in all countries the bank is operating and the asset-liability structure may be very opaque. Only under the rare circumstances that the parent bank is not committed to the subsidiary's survival and allows it to operate as an entirely separate entity, can a crisis be resolved by host country authorities alone.

In general where banks operate across borders there are Memoranda of Understanding about cooperation between home-and host country supervisors. These memoranda are typically very general. For example, in the EU report from The Economic and Financial Committee quoted above, stating that "there is no blue print for crisis resolution", the following statement covers coordination and the assignment of responsibility for decision making with respect to crisis management:

"the presumption in international banking supervision is that the home country authorities are responsible for decisions on crisis management". However, "The principle of home country control is not directly applicable to foreign subsidiaries, as the host country authorities are obliged to treat these as domestic institutions with their own legal identity. In the event of a crisis 
at a foreign subsidiary, the host country supervisor - which is in fact the subsidiary's home country supervisor - can take any preventive measure envisaged in this context." Since most international activity takes place in subsidiaries there is very little guidance in these statements. Thus, if a crisis occurs in an international EU bank, ad hoc solutions must be developed quickly in committees including central banks, financial supervisors and ministries in the countries concerned. Politics of fiscal burden sharing and other national concerns easily become the major issues in negotiations rather than long-term consequences for incentives of stakeholders in banks.

The Banking Directives of the EU state the principles of Home Country Control, Mutual Recognition (of law, regulation and supervision), home country deposit insurance coverage, and the free establishment of banks across borders. These principles seem to be designed for banks operating cross borders through branches rather than subsidiaries. Current EU practices in banking stand in stark contrast to these principles. Many EU countries' attitude to foreign banks and their home country supervisors is characterized by discrimination and distrust rather than mutual recognition.

An EU test case of branch banking is under way. Nordea is a Nordic bank created in 2000 by the mergers of four systemically important banks in four countries. Its strategy is to operate across the four countries in a unified functional organization although its legal organization consists of subsidiaries in the different countries. The response of the supervisors in Denmark, Finland, Norway and Sweden has been to form a joint Nordea committee with a number of joint sub-committees to be able to supervise the bank by function across the legal entities.

Nordea has recently proposed to re-organize to form an EU-company headquartered in Sweden with branches in the other three countries. The supervisors have not yet approved the organization but if they do If the reorganization of Nordea turns out to be successful for the bank and the supervisors it can pave the way for expanded cross-border banking in the EU in particular.

On the face of it, the branch structure, if implemented, simplifies both the bank's organization and the supervisory responsibility. Clearly, greater correspondence between legal and functional organizations is an advantage from an internal efficiency point of view.

Based on the Nordea case Goldberg, Sweeney and Wihlborg (2005) discuss alternative approaches for supervision of cross-country banking through branches. They list five possible "models" for supervision of a bank with headquarter in Sweden and branches in the other three countries. First, the supervisors can continue with the current inter-supervisory committee approach, while depositors are covered by systems of deposit insurance in the host countries. Although this solution is contrary to EU principles, it is the solution that is closest to the current approach to host country subsidiaries. Second, the inter-supervisory committee approach could continue while depositors in all branches become covered by the Swedish deposit insurance scheme. Third, there is the formal "home country" EU-model wherein both supervisory responsibility and deposit insurance for all branches become entirely Swedish in the Nordea case. A fourth model would place supervisory responsibility in Sweden and deposit insurance in the host countries. Last, a Nordic or European supervisory authority and deposit insurance system could be established.

The last "model" is ruled out as politically unrealistic, as well as contrary to the EU principle of institutional competition by means of mutual recognition. ${ }^{5}$. We have to consider national supervisory authorities as the realistic institutional structure for the foreseeable future. The lender-of-last-resort (LOLR) function is similarly a national responsibility for the central banks ${ }^{6}$. 
An efficient supervisory structure should be incentive compatible in the sense that supervisory responsibility coincides with risk taking through deposit insurance responsibility. In addition to the one supervisor-one deposit insurance scheme, the two approaches that satisfy this condition are the first and the third. Under the first approach supervisors role remain similar to their role with the subsidiary organization. It is questionable whether the bank will be able fully implement the branch organization under this approach. Thus we are left with the third "home country" approach as envisioned in the EU Directives.

The advantages with the "home country approach" are that the organization of regulation and supervision, as well as the organization of the bank can become relatively transparent with clear assignment of responsibility. Market discipline of the bank's behavior may also be enhanced because, from the home country perspective, the bank may become "to big to save". Statements to the effect that depositors and other creditors are not protected beyond the explicit, partial insurance scheme become credible. Therefore, market discipline is likely to have a strong effect on the bank's behavior with respect to risk-taking and capital structure. In this way, socalled moral hazard problems in the bank's risk-taking are reduced substantially.

The mentioned advantages do not come automatically, however. As noted, mutual recognition of foreign supervisors' responsibility for large parts of the domestic banking systems requires trust in the effectiveness and fairness of the foreign supervisors. This trust requires institutional support in the form of supervisory organization and distress resolution procedures. ${ }^{7}$ Host country supervisors must rely on the home country supervisor to treat all branches fairly in a crisis situation, and they must have trust in the home country supervisor as head crisis manager. If this trust and acceptance does not exist, the host-country supervisors may intervene in a crisis to take over and bailout the branches in their countries. If markets expect this to happen, then the market discipline is going to be weak. Thus, rules for resolution of a crisis in a bank need to be clear and credible ex ante. These rules need to include binding measures for "prompt corrective action". 8

The rules for "prompt corrective action" must assure all countries involved that the intervention will be fair in relation to all branches and creditors independent of country. For the home-country supervisor to obtain credibility as the supervisor of branches in all countries, the supervisors in the host countries need to be informed about all supervisory activities and the results of these activities. The responsible supervisor must be able to obtain local expertise from the other supervisors upon request. Responsibility must not thereby be shifted towards the host countries, however. One solution for the home-country supervisor is to set up local "branches" with local employees.

The supervisors in the host countries must contribute to the credibility of the regulatory regime by making it clear that they take no regulatory, supervisory, or crisis resolution responsibility, but they accept the ex ante determined rules for structured intervention and partial deposit insurance.

If these principles were implemented, distress resolution procedures would become the subject of institutional competition. The government that wants to support the competitiveness of its banking industry can do this by implementing strong rule based bank insolvency procedures.

There is also concern that the potential differences in deposit insurance coverage between domestic and foreign banks operating in the same country could lead to politically unacceptable consequences in case a foreign bank with relatively low coverage fails. In the US, branches of foreign banks must join the US deposit insurance system and, therefore, US regulators also 
restrict the operations of foreign branches. The benefits of branch banking cannot be realized under these conditions.

If differences in deposit insurance coverage can be accepted, the coverage becomes the subject of institutional competition as well. Relatively low coverage reduces the international competitiveness of banks. Thus, the government that fears the potential costs associated with the failure of domestic bank with large international branch operations would keep the insurance coverage relatively low.

Finally, the institutional support for cross-border banking through branches must include mutual recognition of insolvency procedures in the sense that host countries accept the home country's jurisdiction over bank assets located in the host country. International agreements of this kind with respect to general bankruptcy law exist among some countries.

\section{Empirical evidence on determinants of credibility of non-insurance as disciplinary device}

In this section we use data from 56 developed and emerging market countries to test our propositions with respect to the relation between credibility of non-insurance of banks' creditors and market discipline, as well as with respect to institutional determinants of this relation. In particular, we want to estimate the impact of bank insolvency procedures such as PCA The analysis follows Angkinand and Wihlborg (AW) (2005a), wherein lack of market discipline is captured by two proxies. One is the occurrence of banking crisis, which is identified by a banking crisis dummy ${ }^{9}$. This dummy is given a value of one in years when a country experienced a banking crisis during 1985-2003. The estimation methodology is a logit regression.

The second proxy for market discipline is the share of non-performing loans relative to total loans in the banking industry in each country and year. The data is taken from IMF's Financial Stability Reports and covers the years 1998-2003. Table 1 presents descriptive statistics for the variables used in the estimations.

The main hypothesis tested in AW (2005a) is that market discipline is increasing with the extent of credible non-insurance of banks' creditors. ${ }^{10}$ Lacking a direct proxy for the extent of credible non-insurance AW argue that there is an inverse U-shaped relationship between the extent of credible non-insurance and explicit deposit insurance coverage. In other words, we expect U-shaped relationships between the lack of market discipline (degree of moral hazard) and explicit deposit insurance coverage, and between the probability of banking crisis and explicit deposit insurance coverage. Figure 1 from AW (2005a) illustrates the hypothesized relationships.

The U-shaped curve in the figure depends on an upward sloping relation between explicit deposit insurance and (lack of) market discipline (moral hazard) at a given level of implicit guarantees, and a downward sloping relation showing how the credibility of non-insurance increases with higher explicit coverage. Extensive non-insurance has no credibility because authorities are compelled to intervene rapidly to guarantee depositors' funds in a crisis. As the explicit coverage increases the credibility of non-insurance increases enhancing market discipline while the increasing explicit coverage also reduces market discipline. The U-shaped relation is not a mathematical necessity but based on the conjecture that there is a degree of partial explicit deposit insurance that maximizes the extent of credible non-insurance.

AW (2005a) find that the positive quadratic relationship between (lack of) market discipline and explicit deposit insurance coverage is significant in a panel data analysis of banking crises in 140 countries, as well as in sub-samples for emerging market economies and developed economies, for the period 1985-2003 when the banking crisis dummy is the dependent 
Table (1) Descriptive Statistics

\begin{tabular}{|c|c|c|c|c|c|}
\hline Variable & Obs & Mean & Std.Dev. & Min & Max \\
\hline Banking Crisis Dummy & 856 & 0,2313 & 0,4219 & 0 & 1 \\
\hline NPLs (\%Total Loans) & 291 & 8,4464 & 7,9546 & 0,4 & 42,9 \\
\hline Real GDP Per Capita & 856 & 118,9744 & 107,2241 & 1,9549 & 405,265 \\
\hline Real GDP Growth $\mathrm{t}-1$ & 856 & 3,1872 & 3,8005 & $-22,9341$ & 18,8304 \\
\hline Domestic Credit $_{\mathrm{t}-1}$ & 856 & 84,0484 & 50,0293 & 11,0303 & 321,7523 \\
\hline M2 to Reserve ${ }_{t-1}$ & 856 & 9,2655 & 9,2589 & 0,7784 & 63,9489 \\
\hline Inflation $_{\mathrm{t}-1}$ & 856 & 19,888 & 170,7851 & $-3,9615$ & 410,241 \\
\hline Real Interest Rate $\mathrm{t}-1$ & 856 & 8,1991 & 17,6842 & $-91,7244$ & 112,1223 \\
\hline \multicolumn{6}{|c|}{ Developed and Emerging Market Countries } \\
\hline Covdep & 853 & 1,0492 & 1,0232 & 0 & 3 \\
\hline Comprehensive DI & 851 & 1,2021 & 1,0689 & 0 & 4 \\
\hline PCA & 853 & 4,1887 & 1,8641 & 1 & 8 \\
\hline CA1 & 853 & 18,0184 & 10,2082 & 0 & 42 \\
\hline CA2 & 853 & 14,2311 & 8,2735 & 0 & 36 \\
\hline \multicolumn{6}{|l|}{ Developed Countries } \\
\hline Covdep & 380 & 1,1303 & 0,9545 & 0 & 3 \\
\hline Comprehensive DI & 380 & 1,5263 & 0,9647 & 0 & 3 \\
\hline CAEI & 380 & 3,5895 & 2,0915 & 1 & 8 \\
\hline CA1 & 380 & 19,6009 & 11,707 & 3,17 & 42 \\
\hline CA2 & 380 & 16,1976 & 9,6132 & 2,5 & 36 \\
\hline \multicolumn{6}{|c|}{ Emerging Market Countries } \\
\hline Covdep & 473 & 0,9841 & 1,0717 & 0 & 3 \\
\hline Comprehensive DI & 471 & 0,9406 & 1,0782 & 0 & 4 \\
\hline CAEI & 473 & 4,6702 & 1,4961 & 1 & 6 \\
\hline CA1 & 473 & 16,7471 & 8,6265 & 0 & 36 \\
\hline CA2 & 473 & 12,6513 & 6,6136 & 0 & 30 \\
\hline
\end{tabular}


Figure 1 The Relationship Between (Lack of) Market Discipline and Explicit Deposit Insurance Coverage (Source: Angkinand and Wihlborg, 2005a)

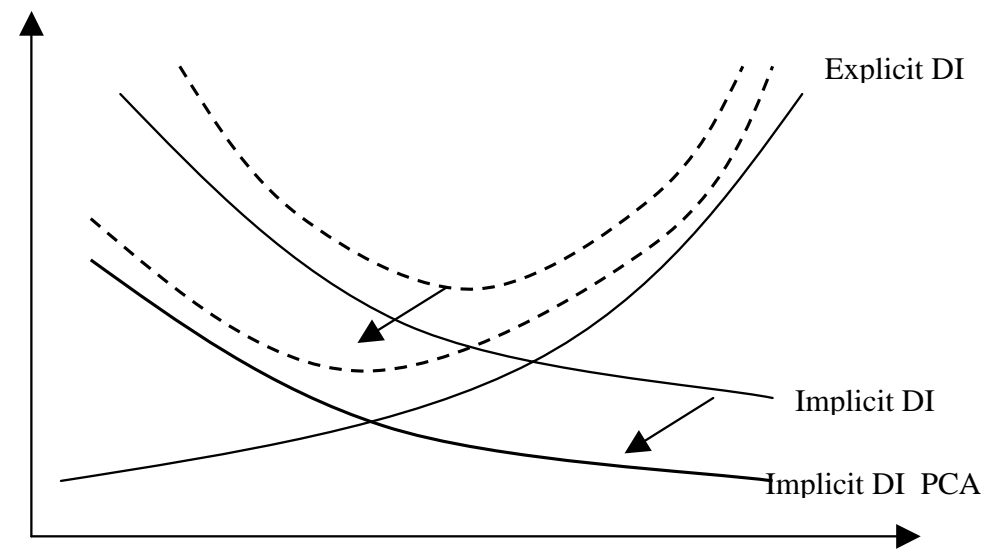


Figure (2) The Predicted Probability of Banking Crises and NPLs (\%Total Loans)
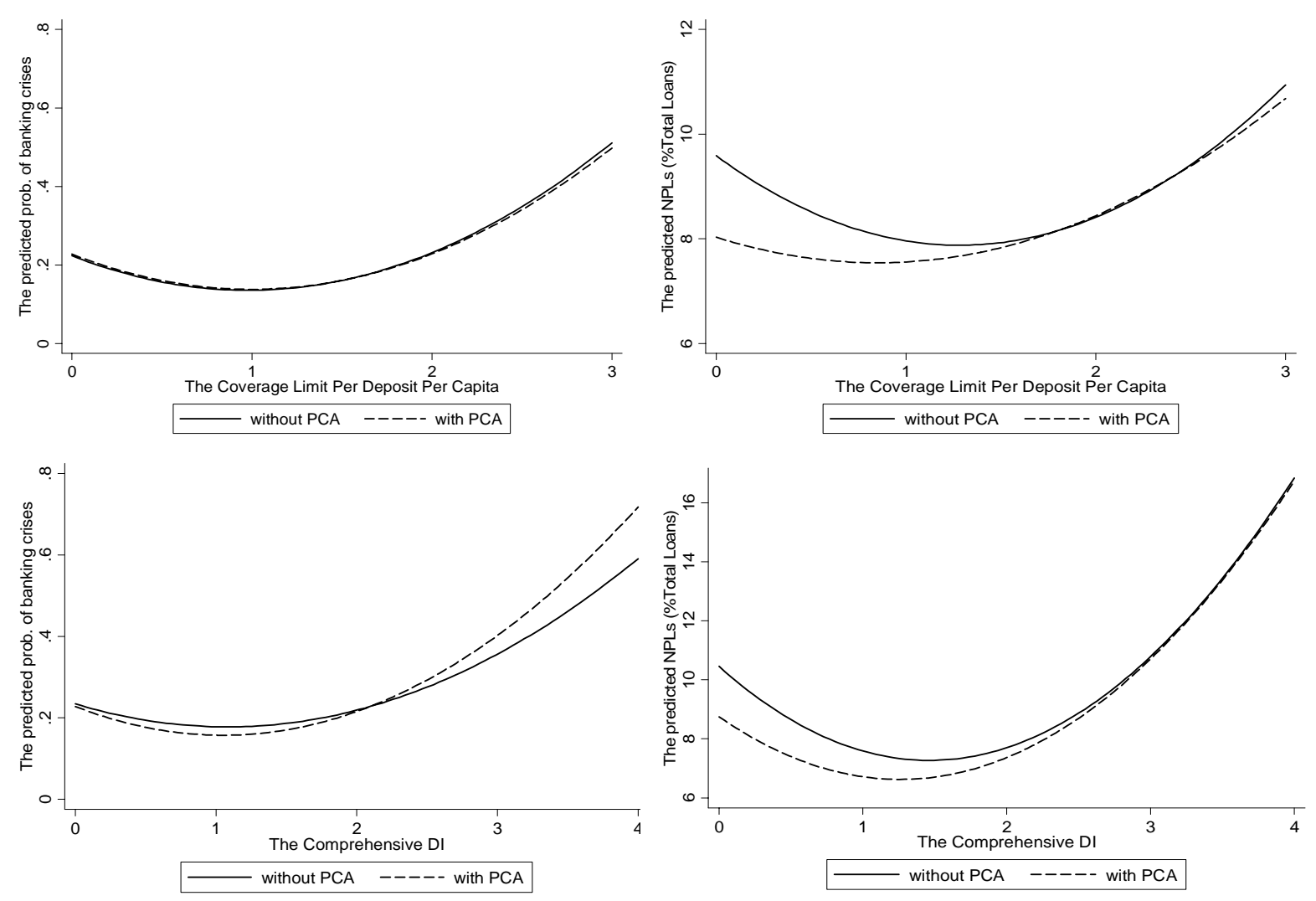
variable, and for the period of 1998-2003 when the non-performing loans variable is the dependent variable. The results for 59 emerging and developed market economies combined are reproduced in columns (1) (banking crisis dummy) and (5) (non-performing loans) in Table 2. Explicit coverage is the maximum coverage per deposit relative to total deposits per capita. ${ }^{11}$ The U-shaped curves in Figure 2 show the relation between each (lack of) market discipline proxy and explicit coverage under the assumption that all control variables take on their average values for the period. Appendix A shows the definitions of all variables including the control variables used in the logit analysis and the OLS regressions..

Next we turn to the impact of bank insolvency procedures on the credibility of noninsurance and market discipline. Figure 1 shows how we expect insolvency procedures to affect (lack of) market discipline. Strengthened rule based procedures should increase the credibility of non-insurance, increase market discipline and, therefore shift the curve describing the relation between implicit insurance and explicit coverage down. As a consequence, the U-shaped curve should shift down and the minimum probability of banking crisis should occur at a lower level of explicit deposit insurance coverage.

As noted, there is little variation across the countries with respect to formal insolvency procedures. In Section 3 we identified the US and UK as countries with explicit rule based procedures. Other countries differ with respect to the supervisors' powers to apply corrective action procedures as shown in data analyzed in Barth et al (2004). We combine the latter data for Power of Corrective Action (scores 1-6) and the observations for the two countries in one variable (CAEI) by adding one to the UK score beginning in 1998 and two to the US score beginning in 1992. Thereby we want to capture the benefits of explicit distress resolution procedures. $^{12}$

Countries also differ in terms of "quality of institutions" more generally as reflected in commonly used measures of "Rule of Law" and "Lack of Corruption". We hypothesize that stronger powers for corrective action in combination with higher quality of institutions make the supervisors' approach to distress resolution for banks more predictable, contributing to credibility of non-insurance of creditors who are not explicitly insured.

Table 2, columns (2), (3) and (4), and columns (6), (7) and (8) show the impact of institutional variables on the two proxies for market discipline. Columns (2) and (6) show the results when the CAEI-variable interacts with explicit deposit insurance coverage allowing the U-shape to shift. The results show that the CAEI variable shifts the curve downwards with a significant impact on the probability of banking crisis, while the impact on non-performing loans is significant both with respect to shape (interactive term) and minimum level. Figure 2 shows how the CAEI variable affects the U-shaped relationships. The shift is substantially larger when the non-performing loans variable is used as market discipline proxy. Furthermore, the shift downwards is larger when the explicit coverage is small as hypothesized.

In columns (3) and (4), and (7) and (8) the institutional variables CA1 and CA2 combines the CAEI variable for corrective action and two proxies for institutional quality. CA1 is CAEI multiplied by a "Rule of Law" score for each country. In CA2 a (lack of) corruption index is used. Column 4 in Table 2 shows a substantial improvement in banking crisis prediction when the corruption variable interacts with both CAEI and deposit insurance coverage. In column 7, where market discipline is captured by non-performing loans, Rule of Law interacting with CAEI has a significant impact..

We do not want to push the interpretation of these results too far here, since so few countries have explicit distress resolution procedures for banks. We can say that corrective action 
Table (2) The Credibility of Non-Insurance, Deposit Insurance Coverage (proxied by Covdep), and Corrective Action

\begin{tabular}{|c|c|c|c|c|c|c|c|c|}
\hline & (1) & (2) & (3) & (4) & (5) & (6) & (7) & (8) \\
\hline Method/Dependent variable & \multicolumn{4}{|c|}{ Logit Estimation/Crisis Dummy } & \multicolumn{4}{|c|}{ OLS/NPLs } \\
\hline Constant & $\begin{array}{c}-0.8798 * * * \\
(0.2621)\end{array}$ & $\begin{array}{c}-1.7679 * * * \\
(0.4709)\end{array}$ & $\begin{array}{c}-0.5196 * * * \\
(0.3990)\end{array}$ & $\begin{array}{c}-0.6270^{*} \\
(0.3703)\end{array}$ & $\begin{array}{c}13.2322 * * * \\
(1.0220)\end{array}$ & $\begin{array}{c}7.2992 * * * \\
(1.4402)\end{array}$ & $\begin{array}{c}10.7746 * * * \\
(1.1978)\end{array}$ & $\begin{array}{c}11.2417^{* * *} \\
(1.2365)\end{array}$ \\
\hline Real GDP Per Capita & $\begin{array}{c}-0.0061 * * * \\
(0.0011)\end{array}$ & $\begin{array}{c}-0.0060^{* * *} \\
(0.0013)\end{array}$ & $\begin{array}{c}-0.0057 * * * \\
(0.0012)\end{array}$ & $\begin{array}{c}-0.0058^{* * *} \\
(0.0012)\end{array}$ & $\begin{array}{c}-0.0528 * * * \\
(0.0047)\end{array}$ & $\begin{array}{c}-0.0450 * * * \\
(0.0040)\end{array}$ & $\begin{array}{c}-0.0470 * * * \\
(0.0042)\end{array}$ & $\begin{array}{c}-0.0470 * * * \\
(0.0042)\end{array}$ \\
\hline Real GDP Growth ${ }_{t-1}$ & $\begin{array}{c}-0.1357 * * * \\
(0.0235)\end{array}$ & $\begin{array}{c}-0.1299 * * * \\
(0.0245)\end{array}$ & $\begin{array}{c}-0.1428 * * * \\
(0.0249)\end{array}$ & $\begin{array}{c}-0.1321 * * * \\
(0.0245)\end{array}$ & $\begin{array}{c}-0.3940 * * * \\
(0.1441)\end{array}$ & $\begin{array}{c}-0.4691 * * * \\
(0.1366)\end{array}$ & $\begin{array}{c}-0.4931 * * * \\
(0.1491)\end{array}$ & $\begin{array}{c}-0.4361 * * * \\
(0.1418)\end{array}$ \\
\hline Domestic Credit $_{\mathrm{t}-1}$ & $\begin{array}{c}0.0084 * * * \\
(0.0025)\end{array}$ & $\begin{array}{c}0.0089 * * * \\
(0.0027)\end{array}$ & $\begin{array}{c}0.0067 * * \\
(0.0029)\end{array}$ & $\begin{array}{c}0.0078 * * * \\
(0.0028)\end{array}$ & $\begin{array}{c}0.0409 * * \\
(0.0092)\end{array}$ & $\begin{array}{c}0.0344 * * * \\
(0.0088)\end{array}$ & $\begin{array}{c}0.0347 * * * \\
(0.0097)\end{array}$ & $\begin{array}{c}0.0399 * * * \\
(0.0106)\end{array}$ \\
\hline M2 to Reserve ${ }_{t-1}$ & $\begin{array}{c}0,0002 \\
(0.0110)\end{array}$ & $\begin{array}{l}-0,0004 \\
(0.0109)\end{array}$ & $\begin{array}{l}-0,0046 \\
(0.0117)\end{array}$ & $\begin{array}{l}-0,0001 \\
(0.0111)\end{array}$ & $\begin{array}{c}-0.0650^{* *} \\
(0.0274)\end{array}$ & $\begin{array}{c}-0.0800^{* * * *} \\
(0.0238)\end{array}$ & $\begin{array}{c}-0.0882 * * * \\
(0.0266)\end{array}$ & $\begin{array}{c}-0.0710^{* * * *} \\
(0.0254)\end{array}$ \\
\hline Inflation $_{\mathrm{t}-1}$ & $\begin{array}{c}-0.0050 * * * \\
(0.0016)\end{array}$ & $\begin{array}{c}-0.0040^{*} \\
(0.0023)\end{array}$ & $\begin{array}{c}-0.0060 * * * \\
(0.0019)\end{array}$ & $\begin{array}{c}-0.0053 * * * \\
(0.0018)\end{array}$ & $\begin{array}{c}0,0029 \\
(0.0022)\end{array}$ & $\begin{array}{l}-0,0261 \\
(0.0411)\end{array}$ & $\begin{array}{c}0,0028 \\
(0.0023)\end{array}$ & $\begin{array}{l}0.0041^{*} \\
(0.0023)\end{array}$ \\
\hline Real Interest Rate ${ }_{t-1}$ & $\begin{array}{l}-0,0022 \\
(0.0052)\end{array}$ & $\begin{array}{c}-0,002 \\
(0.0052)\end{array}$ & $\begin{array}{l}-0,0062 \\
(0.0059)\end{array}$ & $\begin{array}{l}-0,0054 \\
(0.0062)\end{array}$ & $\begin{array}{c}0,0297 \\
(0.0196)\end{array}$ & $\begin{array}{c}0,0256 \\
(0.0182)\end{array}$ & $\begin{array}{c}0.0327^{* *} \\
(0.0186)\end{array}$ & $\begin{array}{c}0.0406^{* *} \\
(0.0190)\end{array}$ \\
\hline $\operatorname{Covdep}_{\mathrm{t}-1}$ & $\begin{array}{c}-1.1669 * * * \\
(0.2761)\end{array}$ & $\begin{array}{c}-1.0697 * * * \\
(0.3002)\end{array}$ & $\begin{array}{c}-1.3432 * * * \\
(0.2982)\end{array}$ & $\begin{array}{c}-1.2623 * * * \\
(0.2922)\end{array}$ & $\begin{array}{l}-0,6036 \\
(1.2024)\end{array}$ & $\begin{array}{l}1.9717^{*} \\
(1.1463)\end{array}$ & $\begin{array}{c}1,5635 \\
(1.2062)\end{array}$ & $\begin{array}{l}1,1876 \\
(1.1303)\end{array}$ \\
\hline$(\text { Covdep } \times \text { Covdep })_{\mathrm{t}-1}$ & $\begin{array}{c}0.5852 * * * \\
(0.0962)\end{array}$ & $\begin{array}{c}0.6181^{* * *} \\
(0.1037)\end{array}$ & $\begin{array}{c}0.5022^{* * *} \\
(0.1031)\end{array}$ & $\begin{array}{c}0.5426^{* * *} \\
(0.1024)\end{array}$ & $\begin{array}{c}0,3983 \\
(0.4239)\end{array}$ & $\begin{array}{c}0,7885 \\
(0.5175)\end{array}$ & $\begin{array}{l}-0,1323 \\
(0.4449)\end{array}$ & $\begin{array}{c}0,1626 \\
(0.4861)\end{array}$ \\
\hline$\left(\text { CAEI }_{t-1} \times(\text { Covdep } \times \text { Covdep })\right)_{t-1}$ & & $\begin{array}{l}-0,0128 \\
(0.0168)\end{array}$ & & & & $\begin{array}{c}-0.2849 * * * \\
(0.0737)\end{array}$ & & \\
\hline CAEI $_{t-1}$ & & $\begin{array}{c}0.1703^{* *} \\
(0.0713)\end{array}$ & & & & $\begin{array}{c}1.0381 * * * \\
(0.2511)\end{array}$ & & \\
\hline$\left(\text { CA1 }_{\mathrm{t}-1} \times(\text { Covdep } \times \text { Covdep })\right)_{\mathrm{t}-1}$ & & & $\begin{array}{c}0.0106 * * * \\
(0.0037)\end{array}$ & & & & $\begin{array}{l}-0,0113 \\
(0.0110)\end{array}$ & \\
\hline CA $1_{t-1}$ & & & $\begin{array}{c}-0,007 \\
(0.0113)\end{array}$ & & & & $\begin{array}{l}0.0768^{*} \\
(0.0468)\end{array}$ & \\
\hline$\left(\mathrm{CA} 2_{\mathrm{t}-1} \times(\text { Covdep } \times \text { Covdep })\right)_{\mathrm{t}-1}$ & & & & $\begin{array}{c}0,0063 \\
(0.0048)\end{array}$ & & & & $\begin{array}{c}-0.0353^{13 \%} \\
(0.0231)\end{array}$ \\
\hline $\mathrm{CA} 22_{\mathrm{t}-1}$ & & & & $\begin{array}{l}-0,0124 \\
(0.0142)\end{array}$ & & & & $\begin{array}{c}0,0234 \\
(0.0598)\end{array}$ \\
\hline No. of observations & 889 & 853 & 853 & 853 & 302 & 290 & 291 & 291 \\
\hline$\%$ correctly predicted & $79,19 \%$ & $79,37 \%$ & $78,74 \%$ & $87,97 \%$ & - & - & - & - \\
\hline Wald Chi-Square (F-statistics) ${ }^{\dagger}$ & 116,94 & 109,54 & 120,84 & 113,92 & 53,76 & 27,96 & 45,63 & 46,66 \\
\hline Prob > Chi-Square $($ Prob > F) & 0.0000 & 0.0000 & 0.0000 & 0.0000 & 0.0000 & 0.0000 & 0.0000 & 0.0000 \\
\hline Pseudo R2 (R2) & 0,1302 & 0,1333 & 0,1363 & 0,1279 & 0,4329 & 0,4655 & 0,4377 & 0,4391 \\
\hline Log-Likelihood (Root MSE) & $-419,64$ & $-400,56$ & $-399,89$ & $-403,74$ & 6,7098 & 5,9187 & 6,0703 & 6,0629 \\
\hline
\end{tabular}

${ }^{*}, * *, * * *$ indicate the significance level of $10 \%, 5 \%$, and $1 \%$ respectively. The numbers in parentheses are robust standard errors of estimated coefficients. ${ }^{\top}$ Statistics in parenthesis is for the OLS regressions. 
Figure (3) The Predicted NPLs (\%Total Loans) for Each Country in the Sample in 2003
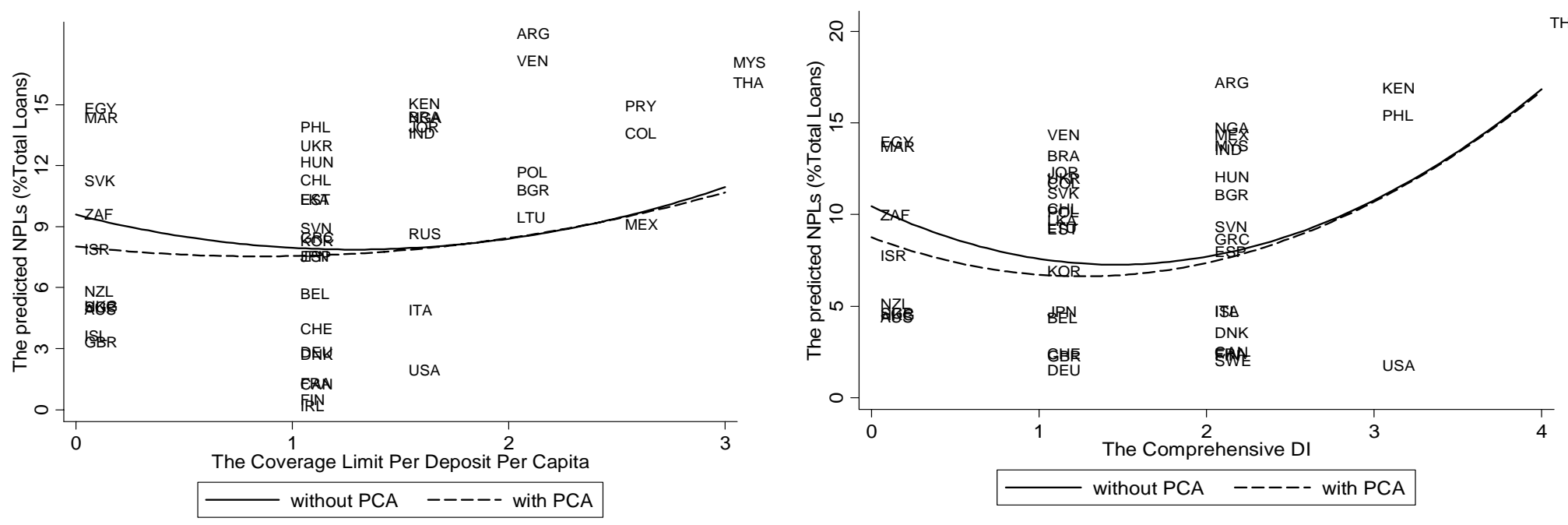
Table (3) The Credibility of Non-Insurance, the Deposit Insurance Coverage (proxied by Comprehensive DI), and Corrective Action

\begin{tabular}{|c|c|c|c|c|c|c|c|c|}
\hline & (1) & (2) & (3) & (4) & (5) & (6) & (7) & (8) \\
\hline Method/Dependent variable & \multicolumn{4}{|c|}{ Logit Estimation/Crisis Dummy } & \multicolumn{4}{|c|}{ OLS/NPLs } \\
\hline Constant & $\begin{array}{c}-0.9550^{* * *} \\
(0.2552)\end{array}$ & $\begin{array}{c}-2.3125^{* * *} \\
(0.5364)\end{array}$ & $\begin{array}{c}-1.0880^{* * *} \\
(0.3951)\end{array}$ & $\begin{array}{c}-0.0058^{* * *} \\
(0.0012)\end{array}$ & $\begin{array}{c}13.5017^{* * *} \\
(1.1134)\end{array}$ & $\begin{array}{c}9.1291^{* * * *} \\
(2.2701)\end{array}$ & $\begin{array}{c}8.9723^{* * *} \\
(1.4817)\end{array}$ & $\begin{array}{c}13.5246^{* * *} \\
(1.5870)\end{array}$ \\
\hline Real GDP Per Capita & $\begin{array}{c}-0.0059^{* * *} \\
(0.0011)\end{array}$ & $\begin{array}{c}-0.0071 * * * \\
(0.0014)\end{array}$ & $\begin{array}{l}-0.0059 * * * \\
(0.0012)\end{array}$ & $\begin{array}{c}-0.1289 * * * \\
(0.0244)\end{array}$ & $\begin{array}{l}-0.0520 * * * \\
(0.0043)\end{array}$ & $\begin{array}{l}-0.0437 * * * \\
(0.0040)\end{array}$ & $\begin{array}{c}-0.0470 * * * \\
(0.0038)\end{array}$ & $\begin{array}{l}-0.0444 * * * \\
\quad(0.0038)\end{array}$ \\
\hline Real GDP Growth ${ }_{t-1}$ & $\begin{array}{c}-0.1339 * * * \\
(0.0231)\end{array}$ & $\begin{array}{c}-0.1261 * * * \\
(0.0244)\end{array}$ & $\begin{array}{c}-0.1307 * * * \\
(0.0244)\end{array}$ & $\begin{array}{c}0.0097 * * * \\
(0.0028)\end{array}$ & $\begin{array}{c}-0.4082^{* * *} \\
(0.1330)\end{array}$ & $\begin{array}{c}-0.4845 * * * \\
(0.1332)\end{array}$ & $\begin{array}{c}-0.4973 * * * \\
(0.1346)\end{array}$ & $\begin{array}{c}-0.4620 * * * \\
(0.1359)\end{array}$ \\
\hline Domestic Credit $_{\mathrm{t}-1}$ & $\begin{array}{c}0.0091 * * * \\
(0.0026)\end{array}$ & $\begin{array}{c}0.0108 * * * \\
(0.0028)\end{array}$ & $\begin{array}{c}0.0089 * * * \\
(0.0027)\end{array}$ & $\begin{array}{c}-0.0118 * * * \\
(0.0113)\end{array}$ & $\begin{array}{c}0.0380^{* * * *} \\
(0.0081)\end{array}$ & $\begin{array}{c}0.0262 * * * \\
(0.0081)\end{array}$ & $\begin{array}{c}0.0309 * * * \\
(0.0076)\end{array}$ & $\begin{array}{c}0.0271^{* * *} \\
(0.0085)\end{array}$ \\
\hline M2 to Reserve ${ }_{t-1}$ & $\begin{array}{l}-0,0165 \\
(0.0112)\end{array}$ & $\begin{array}{l}-0,0101 \\
(0.0109)\end{array}$ & $\begin{array}{l}-0,0154 \\
(0.0121)\end{array}$ & $\begin{array}{l}-0,0028 \\
(0.0023)\end{array}$ & $\begin{array}{c}-0.0782^{* * *} \\
(0.0280)\end{array}$ & $\begin{array}{c}-0.0824 * * * \\
(0.0276)\end{array}$ & $\begin{array}{c}-0.0677^{* *} \\
(0.0278)\end{array}$ & $\begin{array}{c}-0.0796 * * * \\
(0.0290)\end{array}$ \\
\hline Inflation $_{\mathrm{t}-1}$ & $\begin{array}{l}-0,0031 \\
(0.0023)\end{array}$ & $\begin{array}{l}-0,0028 \\
(0.0023)\end{array}$ & $\begin{array}{l}-0,0029 \\
(0.0024)\end{array}$ & $\begin{array}{c}0,0012 \\
(0.0054)\end{array}$ & $\begin{array}{l}-0,0094 \\
(0.0445)\end{array}$ & $\begin{array}{l}-0,0193 \\
(0.0428)\end{array}$ & $\begin{array}{r}0,0205 \\
(0.0437)\end{array}$ & $\begin{array}{l}-0,0304 \\
(0.0441)\end{array}$ \\
\hline Real Interest Rate ${ }_{t-1}$ & $\begin{array}{c}0.0000 \\
(0.0052)\end{array}$ & $\begin{array}{c}0.0000 \\
(0.0053)\end{array}$ & $\begin{array}{c}0,0001 \\
(0.0054)\end{array}$ & $\begin{array}{l}-0,5407 \\
(0.2901)\end{array}$ & $\begin{array}{c}0,028 \\
(0.0185)\end{array}$ & $\begin{array}{c}0,0266 \\
(0.0178)\end{array}$ & $\begin{array}{c}0.0428^{* *} \\
(0.0187)\end{array}$ & $\begin{array}{r}0,0303 \\
(0.0185)\end{array}$ \\
\hline $\operatorname{Comp}_{t-1}$ & $\begin{array}{l}-0,43 \% \\
(0.2663)\end{array}$ & $\begin{array}{l}-0,2739 \\
(0.2935)\end{array}$ & $\begin{array}{l}-0,4449 \\
(0.2838)\end{array}$ & $\begin{array}{l}0.3671 * \\
(0.1135)\end{array}$ & $\begin{array}{l}-1,2328 \\
(1.1688)\end{array}$ & $\begin{array}{l}-0,1034 \\
(1.1039)\end{array}$ & $\begin{array}{c}0,3065 \\
(1.1788)\end{array}$ & $\begin{array}{l}-1,1702 \\
(1.0686)\end{array}$ \\
\hline$(\text { Comp } \times \text { Comp })_{t-1}$ & $\begin{array}{c}0.2794 * * * \\
(0.0908)\end{array}$ & $\begin{array}{c}0.4566^{* * *} \\
(0.1187)\end{array}$ & $\begin{array}{c}0.2858 * * * \\
(0.0999)\end{array}$ & $\begin{array}{c}-0.0041^{* * * *} \\
(0.0038)\end{array}$ & $\begin{array}{c}0.7268^{* *} \\
(0.4058)\end{array}$ & $\begin{array}{c}0.9025^{*} \\
(0.529)\end{array}$ & $\begin{array}{c}0.9064^{* *} \\
(0.4337)\end{array}$ & $\begin{array}{l}0.7207^{*} \\
(0.4388)\end{array}$ \\
\hline$\left(\mathrm{CAEI}_{\mathrm{t}-1} \times(\mathrm{Comp} \times \mathrm{Comp})\right)_{\mathrm{t}-1}$ & & $\begin{array}{c}-0.0473 * * * \\
(0.0162)\end{array}$ & & & & $\begin{array}{l}-0,0887 \\
(0.0851)\end{array}$ & & \\
\hline $\mathrm{CAEI}_{\mathrm{t}-1}$ & & $\begin{array}{c}0.2536 * * * \\
(0.0833)\end{array}$ & & & & $\begin{array}{c}0.7418^{* *} \\
(0.3663)\end{array}$ & & \\
\hline$\left(\text { CA1 }_{\mathrm{t}-1} \times(\text { Comp } \times \text { Comp })\right)_{\mathrm{t}-1}$ & & & $\begin{array}{c}0,0001 \\
(0.0029)\end{array}$ & & & & $\begin{array}{c}-0.0320^{* * *} \\
(0.0094)\end{array}$ & \\
\hline $\mathrm{CA1}_{\mathrm{t}-1}$ & & & $\begin{array}{l}0,0067 \\
(0.0117)\end{array}$ & & & & $\begin{array}{c}0.1515 * * * \\
(0.0536)\end{array}$ & \\
\hline$\left(\mathrm{CA}_{\mathrm{t}-1} \times(\mathrm{Comp} \times \mathrm{Comp})\right)_{\mathrm{t}-1}$ & & & & $\begin{array}{l}-0,0031 \\
(0.0153)\end{array}$ & & & & $\begin{array}{c}0,0043 \\
(0.0160)\end{array}$ \\
\hline $\mathrm{CA} 2_{\mathrm{t}-1}$ & & & & $\begin{array}{l}-1,0106 \\
(0.3675)\end{array}$ & & & & $\begin{array}{l}-0,0382 \\
(0.0707)\end{array}$ \\
\hline No. of observations & 886 & 853 & 853 & 853 & 301 & 290 & 290 & 290 \\
\hline$\%$ correctly predicted & $77,43 \%$ & $78,55 \%$ & $77,73 \%$ & $77,73 \%$ & - & - & - & - \\
\hline Wald Chi-Square (F-statistics) $^{\dagger}$ & 86,9 & 78,54 & 82,79 & 75,99 & 33,7 & 27,02 & 27,98 & 27,37 \\
\hline Prob > Chi-Square $($ Prob > F) & 0.0000 & 0.0000 & 0.0000 & 0.0000 & 0.0000 & 0.0000 & 0.0000 & 0.0000 \\
\hline Pseudo R2 (R2) & 0,0982 & 0,1099 & 0,0966 & 0,0987 & 0,4469 & 0,472 & 0,478 & 0,4655 \\
\hline Log-Likelihood (Root MSE) & $-434,35$ & $-411,38$ & $-417,53$ & $-416,57$ & 6,6303 & 5,8827 & 5,8495 & 5,9189 \\
\hline
\end{tabular}

${ }^{*}, * *, * * *$ indicate the significance level of $10 \%, 5 \%$, and $1 \%$ respectively. The numbers in parentheses are robust standard errors of estimated coefficients. ${ }^{\dagger}$ Statistics in parenthesis is for the OLS regressions. 
Figure (4) The Predicted Probability of Banking Crises for US and UK

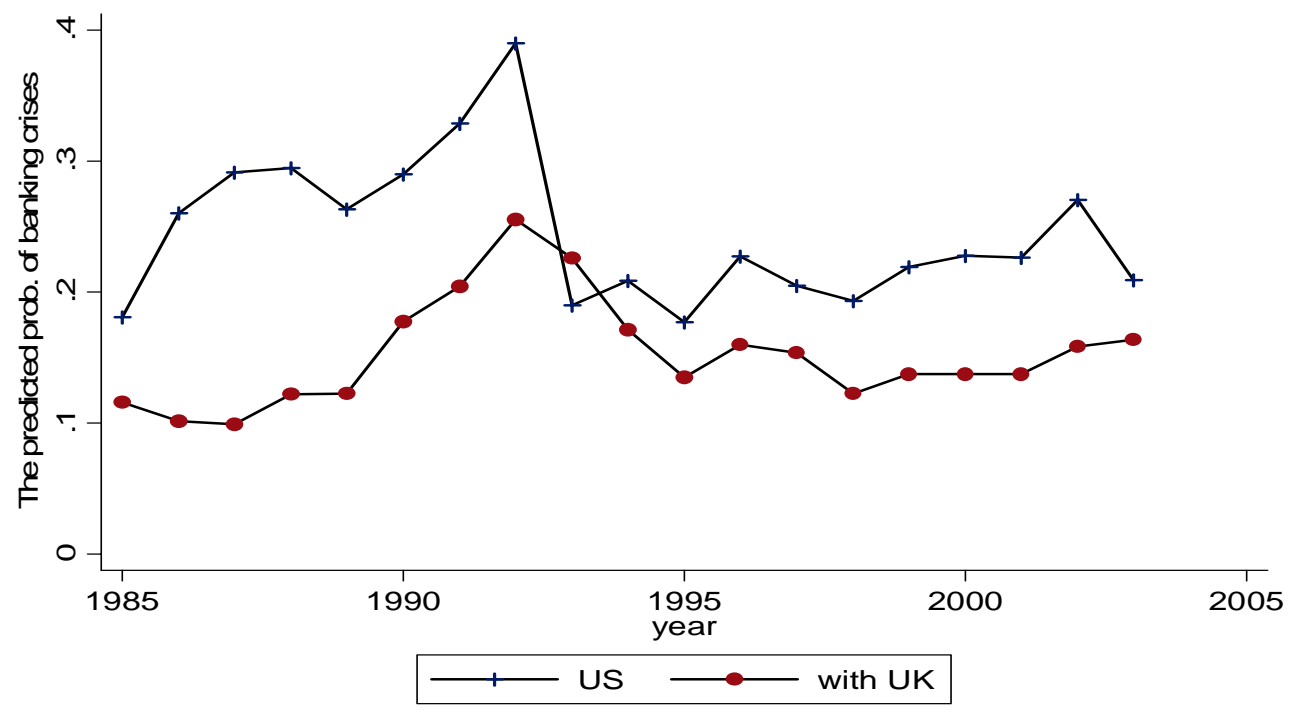


procedures and other institutional factors are relevant for market discipline, although there is not one proxy for quality of institutions that demonstrates a consistent impact on the credibility of non-insurance and market discipline.

Finally in Figure 3 we plot the predicted probability of banking crisis in the US and the UK each year. Changes in the probability depend on shifts in macroeconomic variables as well as shifts in the CAEI variable capturing US and UK distress resolution procedures. There was a shift in the CAEI-score for the US in 1992 when the FDICIA took effect and in 1998 for the UK. Clearly there is a dramatic shift for the US in 1992 but it could depend on macro variables as well.

\section{Conclusions}

We have argued that efficient incentives of banks' creditors, as well as of shareholders and managers, require predetermined rules for dealing with banks in distress, and a group of creditors that are credibly non-insured. Insolvency procedures for banks need to be designed taking the special characteristics of banks and their liquidity role into consideration.

An international overview of distress resolution procedures for banks reveal that only the USA has implemented a set of predetermined rules for dealing with banks before they reach insolvency while the UK has insolvency law that can be applied to banks. These procedures and rules enhance the predictability with respect to distress-related costs and potential losses for shareholders, managers, and creditors of banks. In the EU on the other hand distress resolution procedures seem to be based on the principle that "there is no blue-print for distress resolution"

To realize the full advantages of cross-border branch organizations, supervisors, central banks and governments must come to accept the principles of home country control of banks, mutual recognition, and competition between different degrees of deposit insurance coverage depending on a bank's home country. This acceptance does not come easy and requires important institutional reforms of distress reolution procedures in particular. "Prompt Corrective Action" procedures could be the minimum requirement that enables host country supervisors to trust home country supervision of local branches.

In the last section we provided empirical evidence that market discipline linked to the extent of credible non-insurance of creditors tends to be low when the explicit deposit insurance coverage is very high as well as low. Thus, there is an intermediate degree of coverage that maximizes market discipline. We also tested and found support for the hypothesis that Prompt Corrective Action procedures enhance market discipline and lower the level of explicit deposit insurance coverage that maximizes market discipline. Thus, it could be argued that after the implementation of FDICIA in 1992, there is scope for lowering the deposit insurance coverage in the USA.

\section{References}

Angkinand, Apanard., 2005, "Deposit insurance and financial crises: Investigation of the costbenefit tradeoff”, Claremont Center for Economic Poicy Studies, Claremont Graduate University, Working Paper

Angkinand, Apanard and Clas Wihlborg, 2005a, "Deposit insurance coverage, credibility of non-insurance and banking crisis," Center for Law, Economics and Financial Institutions at CBS (LEFIC), Copenhagen Business School, Working Paper, 
2005b, "Bank insolvency procedures and market discipline in European banking”, LEFIC, Copenhagen Business School, Working Paper

Barth, James R., Gerard Caprio Jr., and Ross Levine, 2004. "The regulation and supervision: What works best?” Journal of Financial Intermediation 13; 205-248.

Caprio, Gerard, Jr. and Daniela Klingebiel, 2003. "Episodes of systemic and borderline financial crises.” The World Bank, Working Paper

Demirgüç-Kunt, Asli, Buybars Karacaovali and Luc Laeven, 2005, "Deposit insurance around the World: A comprehensive database," World Bank Policy Research Working Paper, Washington, DC

Economic and Financial Committee of the EU, 2000, "Report on financial crisis management”, Economic Papers, No 156

European Shadow Financial Regulatory Committee, 1998, "Resolving problem banks in Europe”, Statement No 1, London

Goldberg, Lawrence, Richard. J. Sweeney and Clas Wihlborg, 2005, "Can Nordea show Europe the way? The Financial Regulator, Vol 10, No 2, Sept.

Herring, Richard, 2004, ”International financial conglomerates; Implications for bank insolvency regimes”, Financial Institutions Ceter, The Wharton School, Working Paper

Mayes, David. G., 2004, "The role of the safety net in resolving large cross-border financial institutions”, Bank of Finland, Research Paper.

Wihlborg, Clas, (2005), "Basel II and the Need for Bank Insolvency Procedures”, Financial Markets, Institutions and Instruments, forthcoming

Wihlborg, Clas and Shubhashis Gangopadhyay with Qaizar Hussain, 2001, "Infrastructure requirements in the area of bankruptcy” Brookings-Wharton Papers on Financial Services

\section{Endnotes}

\footnotetext{
${ }^{1}$ The discussion of insolvency procedures for non-banks is based on Wihlborg, Gangopadhyay with Hussain (2001)

2 This section is based on Angkinand and Wihlborg (2005b)

${ }^{3}$ See Wihlborg (2005)

${ }^{4}$ Economic Paper No 156, July 2001 from The Economic and Financial Committee

${ }^{5}$ It must also be noted that Norway is not a member of the EU, while only Finland has joined the Euro.

${ }^{6}$ In the euro-zone, national central banks are formally the LOLR, but the ECB must become involved if liquidity is to be increased.
} 


\footnotetext{
${ }^{7}$ The Swedish FSA seems to favor a structure between the first and fourth approaches while Denmark, Finland and Norway are likely to prefer either the first or second models. Thus, a prediction for the Nordea case is that the first approach will be implemented.

${ }^{8}$ See also Mayes (2004) "The Role of the Safety Net in Resolving Large Cross-border Financial Institutions, Bank of Finland Working Paper.

${ }^{9}$ The banking crisis data is taken from Caprio and Klingebiel (2003)

10 There is a large literature on deposit insurance and banking crisis. We do not review it here, since an extensive review can be found in AW (2005a)

${ }^{11}$ The deposit insurance variable is based on data gathered by the World Bank and presented in Demirguc-Kunt, Karacaovali and Laeven (2005). Other proxies for coverage are also developed there and used in AW (2005a).

${ }^{12}$ Barth, Caprio and Levine multiply their score for power with the existence of a formal capital ratio triggering intervention. We do not use this multiplicative term that makes the score for, for example, the UK zero. The existence of a formal trigger capital ratio for intervention by supervisors may only reflect how Basel capital requirements have been expressed in formal rules. Many countries have accepted the Basel rules without explicit reference to them in formal rules for supervisors..
} 


\begin{tabular}{|c|c|} 
Appendix A. List of Countries \\
\hline Industrial Countries & Emerging Markets \\
\hline Austria & Argentina \\
Australia & Brazil \\
Belgium & Bulgaria \\
Canada & Chile \\
Denmark & China \\
Finland & Colombia \\
Germany & Egypt \\
Greece & Estonia \\
Iceland & Ghana \\
Ireland & Hong Kong \\
Italy & Hungary \\
Japan & India \\
Netherlands & Indonesia \\
New Zealand & Israel \\
Norway & Jordan \\
Portugal & Kenya \\
Spain & Korea \\
Sweden & Lithuania \\
Switzerland & Malaysia \\
United Kingdom & Mexico \\
United States & Morocco \\
& Nigeria \\
& Paraguay \\
& Philippines \\
& Poland \\
& Russia \\
& Singapore \\
& Slovak Republic \\
& Slovenia \\
& South Africa \\
& Sri Lanka \\
& Thailand \\
& Venezuela \\
& \\
& Zimbabwe \\
\hline
\end{tabular}


Appendix B. Data Description

\begin{tabular}{|c|c|c|}
\hline Variable & Description & Source \\
\hline Banking Crisis & $\begin{array}{l}\text { The banking crisis dummy, which is equal to } 1 \text { in a banking crisis year } \\
\text { (both systemic and nonsystemic banking crises), and } 0 \text { otherwise }\end{array}$ & $\begin{array}{l}\text { Caprio and Klingebiel } \\
\text { (2003) }\end{array}$ \\
\hline NPLs & The non-performing loan (\% total assets) & IMF \\
\hline Real GDP Per Capita & GDP per capita (constant 2000 US\$). The data is in 100 U.S.\$ & WDI \\
\hline Real GDP Growth Rate & GDP growth (annual \%) & WDI \\
\hline CA to GDP & Current account balance (\% of GDP) & WDI \\
\hline Domestic Credit & Domestic credit provided by banking sector (\% of GDP) & WDI \\
\hline M2 to Reserve & Money and quasi money (M2) to gross international reserves ratio & WDI \\
\hline Inflation & Inflation, consumer prices (annual \%) & WDI \\
\hline Real Interest Rate & Real interest rate (\%) & WDI \\
\hline $\begin{array}{l}\text { Explicit Deposit } \\
\text { Insurance }\end{array}$ & $\begin{array}{l}\text { The explicit deposit insurance dummy, which is equal to } 1 \text { in a year that } \\
\text { a country has an formal deposit insurance system, and } 0 \text { otherwise. }\end{array}$ & $\begin{array}{l}\text { Demirgüç-Kunt, et al. } \\
\text { (2005) }\end{array}$ \\
\hline $\begin{array}{l}\text { The Ratio of Coverage } \\
\text { Limit to Deposits per } \\
\text { Capita (Covdep) }\end{array}$ & $\begin{array}{l}\text { The ordinal data of the ratio of deposit insurance coverage per deposits } \\
\text { per capita. The value of this variable is assigned based on a value of the } \\
\text { coverage to deposits per capita. This variable is } \\
=0 \text { if there is no explicit deposit insurance coverage } \\
=1 \text { if the coverage to GDP per capita ratio is between }(0,5) \\
=1.5 \text { if the coverage to GDP per capita ratio is between }[5,10) \\
=2 \text { if the coverage to GDP per capita ratio is between }[10,15) \\
=2.5 \text { if the coverage to GDP per capita ratio is greater than or equal } 15 \\
=3 \text { if there is blanket deposit guarantee }\end{array}$ & $\begin{array}{c}\text { Authors' construction } \\
\text { Coverage to GDP per } \\
\text { capita ratio is from } \\
\text { Demirgüç-Kunt, et al. } \\
\text { (2005) }\end{array}$ \\
\hline $\begin{array}{l}\text { Comprehensive Deposit } \\
\text { Insurance }\end{array}$ & $\begin{array}{l}\text { The summation of four dummy variables: } 1 \text {. whether an explicit system } \\
\text { covers foreign deposits, } 2 \text {. whether an explicit system covers interbank } \\
\text { deposits, 3) whether an explicit system has no coinsurance, and } 4 \text { ) } \\
\text { whether the full deposit guarantee is implemented (yes }=1 \text {, no }=0 \text { ). }\end{array}$ & $\begin{array}{c}\text { Authors' construction } \\
\text { Coverage to GDP per } \\
\text { capita ratio is from } \\
\text { Demirgüç-Kunt, et al. } \\
\text { (2005) }\end{array}$ \\
\hline $\begin{array}{l}\text { Corrective Action an } \\
\text { Early Intervention } \\
\text { (CAEI) }\end{array}$ & $\begin{array}{l}\text { CAEI is the aggregated index of } 6 \text { survey questions capturing the extent } \\
\text { of supervisors' prompt corrective action and intervention power. } \\
\text { However, this variable does not consider the existence of a written law } \\
\text { on pre-determined level of bank solvency deterioration (see Angkinand } \\
\text { and Wihlborg, 2005a). This variable is scaled 1-6. The scale is adjusted } \\
\text { to } 7 \text { for the UK after the } 1997 \text { strengthen insolvency procedure, and to } 8 \\
\text { for the US during the post-FDICIA (1992-present). }\end{array}$ & $\begin{array}{c}\text { Authors' construction } \\
\text { (six survey questions } \\
\text { are from Barth, et al., } \\
\text { 2004) }\end{array}$ \\
\hline CA1 & $\begin{array}{l}\text { CA1 = CAEI } \times \text { the rule of law index. The rule of law and order index } \\
\text { with the scale of 1-6; high values indicate better quality of law and order. }\end{array}$ & $\begin{array}{l}\text { Rule of Law Index is } \\
\text { fromInternational } \\
\text { Country Risk Guide }\end{array}$ \\
\hline CA2 & $\begin{array}{l}\text { CA2 = CAEI } \times \text { the corruption index. The corruption index with the scale } \\
\text { of 1-6; high values indicate less corruption. }\end{array}$ & $\begin{array}{l}\text { Corruption Index is } \\
\text { from International } \\
\text { Country Risk Guide }\end{array}$ \\
\hline
\end{tabular}

